\title{
Pengaruh Pendekatan Konstruktivisme Terhadap Karakter Kepercayaan Diri Siswa dalam Pembelajaran Matematika di SMPN 15 Kota Bekasi
}

\author{
Ade Mutiarawati \\ Pengawas Dinas Pendidikan Kota Bekasi \\ ade.mutiarawati23@gmail.com
}

Artikel Info

Tanggal Publikasi

2019-12-30

\section{Kata Kunci}

Konstruktivisme

Kepercayaan Diri

\section{Abstrak}

Tujuan penelitian ini adalah untuk mengetahui pengaruh pendekatan konstruktivisme terhadap karakter kepercayaan diri dalam pembelajaran matematika SMPN 15 Kota Bekasi yang erat kaitannya dengan peningkatan pembelajaran. Metode penelitian yang digunakan adalah metode quasi eksperimen. Populasi pada penelitian ini adalah siswa SMPN 15 Kota Bekasi. Sampel diambil dengan menggunakan teknik random sampling, dengan jumlah sampel pada penelitian ini yaitu 31 siswa. Instrumen yang digunakan dalam penelitian ini adalah angket tertutup sebanyak 21 butir pernyataan. Sebelum digunakan angket ini diujicobakan terlebih dahulu untuk mengukur validitas dan reliabilitas. Berdasarkan perhitungan diperoleh koefisien reliabilitas sebesar 0,945 dengan klasifikasi sangat tinggi. Berdasarkan data hasil penelitian diperoleh rata-rata karakter kepercayaan diri awal siswa, karakter kepercayaan diri akhir siswa dan selisih pada kelas eksperimen masing-masing sebesar 6,67, 8,56 dan 1,89. Setelah dilakukan pengujian hipotesis terhadap selisih kepercayaan diri siswa akhir dengan kepercayaan diri siswa awal diperoleh thitung yaitu 17,782 dengan nilai ttabel untuk $\alpha=0,05$ dan $\mathrm{df}=31$ adalah 1,645. Kriteria nilai thitung $>$ ttabel maka dapat disimpulkan karakter kepercayaan diri akhir siswa kelas eksperimen setelah menggunakan pendekatan konstruktivisme dalam pembelajaran matematika lebih tinggi daripada karakter kepercayaan diri awal siswa. Dengan demikian dapat disimpulkan bahwa pendekatan konstruktivisme berpengaruh signifikan terhadap karakter kepercayaan diri siswa dalam pembelajaran matematika di SMPN 15 Kota Bekas.

\section{PENDAHULUAN}

Karakter Kepercayaan diri merupakan satu diantara aspek-aspek kepribadian yang penting dalam kehidupan manusia (Ergen, 2019; Sokip, Akhyak, Soim, Tanzeh, \& Kojin, 2019). Karakter Kepercayaan diri pada anak berkembang karena adanya pengalaman berinteraksi dengan lingkungannya, yang menjadi sebuah pengetahuan terhadap dirinya sendiri. Pengalaman-pengalaman yang dialami seseorang terutama pada masa kanak-kanak menjadi langkah awal perkembangan rasa percaya diri. Sebagai seorang anak dalam masyarakat, anak memerlukan lingkungan yang dapat memberikan rasa aman dan nyaman, mendapatkan kasih sayang, pengakuan dan penerimaan.

Karakter kepercayaan diri adalah keyakinan seseorang terhadap segala aspek kelebihan yang dimilikinya dan keyakinan tersebut membuatnya merasa mampu untuk bisa mencapai berbagai tujuan di dalam hidupnya (Deni \& Ifdil, 2013; Syam, 2017). Anak yang memiliki karakter kepercayaan diri yang tinggi akan mampu menilai dirinya sendiri, seperti kemampuan, bakat dan hal lain yang dimilikinya. Ia akan merasa yakin dengan kemampuan yang dimilikinya untuk mencapai tujuan hidupnya.

Lingkungan yang sangat mempengaruhi karakter kepercayaan diri anak adalah lingkungan keluarga, sekolah, dan masyarakat (Afriani, 2019; Hariawan, Ulfatin, Huda A. Y., \& Arifin, 2019; Lowery-Moore, Latimer, \& Villate, 2016; Subianto, 2013). Lingkungan keluarga merupakan tempat pertama dan utama yang sangat menentukan baik-buruknya kepribadian anak, dimana awal anak 
diajarkan untuk berkomunikasi, bergaul, kasih sayang, dan bekerja sama. Lingkungan yang kedua yaitu sekolah, dimana anak akan memperoleh pengetahuan yang dapat mengembangkan dan meningkatkan kecerdasannya. Di sekolah, anak juga mendapat kesempatan bergaul dan bekerja sama dengan teman sebaya. Lingkungan ketiga adalah masyarakat, dimana anak dapat menerapkan banyak hal yang diperolehnya dari lingkungan keluarga dan sekolah.

Karakter kepercayaan diri penting bagi anak dalam hubungannya dengan proses sosialisasi dan adaptasi dengan teman-teman dan lingkungannya (Arumdini, Winoto, \& Anwar, 2016; ÖNDER, 2018; Parida, Winarsih, Maksum, \& Adiansha, 2018; Zubaidah, 2019), terutama ketika akan memasuki pendidikan formal, seperti Sekolah Menengah Pertama. Agar dapat melakukan kegiatan khususnya, yaitu belajar, anak perlu melakukan interaksi dengan teman, guru, dan lingkungannya sesuai dengan kemampuannya. Anak dituntut dapat menyesuaikan diri dan membuka diri di lingkungan, khususnya lingkungan sekolah, dimana berani tampil di depan kelas dan berkomunikasi dengan baik serta mengekspresikan keinginan maupun harapan-harapan. Apabila karakter kepercayaan diri tumbuh semakin kuat, maka anak akan semakin dirangsang untuk berani mencoba dan menghadapi keadaan atau masalah baru yang dia hadapi di dalam kegiatan belajarnya di sekolah (Cheeseman \& Klooger, 2018; Fatahi, 2019; ÖNDER, 2018; Soruç \& Griffiths, 2017).

Faktanya, ditemukan faktor-faktor yang menyebabkan siswa kurang karakter kepercayaan diri, yaitu siswa tidak berani bertanya, tidak mampu melakukan kegiatan diskusi dengan baik, serta tidak berani mengerjakan soal di depan kelas, khususnya dalam pembelajaran matematika. Hal tersebut disebabkan adanya sugesti siswa yang takut dengan pembelajaran matematika, kurangnya pemahaman dan pengetahuan yang dimilikinya. Tidak dapat dipungkiri juga, pembelajaran yang diberikan guru kurang efektif dan menyenangkan, karena guru tidak memakai metode, media dan pendekatan yang sesuai dengan materi yang diberikan. Selain itu, terkadang guru tidak menyadari pentingnya pembelajaran yang dapat meningkatkan kepercayaan diri siswa. Hal ini dapat dilihat dari menurunnya tingkat kepercayaan diri siswa, kurangnya keinginan yang tinggi dengan pembelajaran yang disampaikan, serta lemahnya kemampuan anak tentang konsep matematika. Meskipun tidak ada cara belajar yang benar, dan cara mengajar yang baik, setiap individu berbeda dalam kemampuan intelektualnya, sikap, dan kepribadian, maka diperlukan pendekatan pembelajaran yang mengerti karakteristik setiap individu dalam belajar. Pendekatan yang dapat menumbuhkan kepercayaan diri dalam pembelajaran matematika.

Konstruktivisme merupakan suatu proses pembentukan pengetahuan (Alsulami, 2016; Bozkurt, 2017; Kosnik, Menna, Dharamshi, \& Beck, 2018; Rahayu, Danugiri, Sopiany, \& Masalah, 2018; Suparlan, 2019; Tan, 2017). Pembentukan ini dilakukan oleh siswa, ia harus aktif melakukan kegiatan, aktif berpikir, menyusun konsep dan memberi makna tentang hal-hal yang sedang dipelajari. Pengetahuan bukanlah kumpulan fakta dari suatu kenyataan yang sedang dipelajari, melainkan sebagai konstruksi kognitif seseorang terhadap objek pengalaman terhadap lingkungannya. Kelas konstruktivis para siswa diperdayakan pengetahuan berbeda yang dimilikinya, mereka berbagi strategi dan penyelesaian, debat antara satu dengan yang lainnya, berpikir secara kritis tentang cara terbaik untuk menyelesaikan setiap masalah yang dihadapinya.

Pendekatan konstruktivisme telah memfokuskan secara eksklusif pada proses dimana siswa secara individual aktif mengkonstruksi realitas matematika mereka sendiri. Pembelajaran matematika menggunakan pendekatan konstruktivisme peranan guru bukan pemberi jawab akhir atas pertanyaan siswa, melainkan mengarahkan mereka untuk membentuk (mengkonstruksi) pengetahuan matematika sehingga diperoleh struktur matematika, sehingga membuat siswa lebih mengembangkan karakter kepercayaan diri untuk mengekspresikan pengetahuan yang dimilikinya. Dengan begitu jika belajar mengajar menggunakan pendekatan konstruktivisme, karakter kepercayaan diri siswa akan tinggi dan siswa akan menyenangi pembelajaran matematika. 
Berdasarkan temuan di atas, maka penting dilakukan penelitian mengenai pengaruh pendekatan konstruktivisme terhadap karakter kepercayaan diri siswa, sebagai penjelasan dan jawaban dari permasalahan ada atau tidaknya pengaruh pendekatan konstruktivisme terhadap kepercayaan diri siswa SMPN 15 Kota Bekasi.

Rumusan masalah yang digunakan dalam penelitian ini yaitu Apakah pendekatan konstruktivisme berpengaruh signifikan terhadap kepercayaan diri siswa dalam pembelajaran matematika SMPN 15 Kota Bekasi. Sehingga tujuan yang dalam penelitian yaitu untuk mengetahui pengaruh pendekatan konstruktivisme terhadap kepercayaan diri siswa dalam pembelajaran matematika SMPN 15 Kota Bekasi.

\section{METODE PENELITIAN}

Metode yang digunakan dalam penelitian ini yaitu quasi eksperimen design. Metode penelitian quasi eksperimen design adalah metode penelitian yang bertujuan untuk memperoleh informasi yang merupakan perkiraan bagi informasi yang dapat diperoleh dengan eksperimen yang sebenarnya dalam keadaan yang tidak memungkinkan untuk mengontrol atau memanipulasi semua variabel yang relevan (Abidin, Solihatin, Sumantri, \& Adiansha, 2018; Adiansha \& Sumantri, 2017; Adiansha, Sumantri, \& Makmuri, 2018; Misykah \& Adiansha, 2018). Dimana karakter kepercayaan diri yang merupakan data dari penelitian dikelompokkan menjadi dua, yaitu karakter kepercayaan diri awal siswa dan karakter kepercayaan diri akhir siswa dalam pembelajaran matematika setelah menggunakan pendekatan konstruktivisme.

Pada penelitian ini dilakukan pengukuran awal (angket awal) dan pengukuran akhir (angket akhir), penelitian ini menggunakan angket yang sama pada pengukuran awal dan akhir, perlakuan dapat diketahui lebih akurat, karena membandingkan keadaan sebelum dan sesudah diberi perlakuan atau treatment. Perbedaan antara angket awal dan angket akhir merupakan akibat dari perlakuan atau treatment yang diberikan, karena variabel karakter kepercayaan diri hasilnya belum tentu meningkat. Adapun desain yang digunakan dalam penelitian ini adalah tipe The One-Group Pretest-Posttest Design, yang dinyatakan sebagai berikut:

Tabel 1. Desain Penelitian

\begin{tabular}{cccc}
\hline Kelompok & Angket Awal & Perlakuan & Angket Akhir \\
\hline Kelompok Eksperimen & $\mathrm{O}_{1}$ & $\mathrm{X}$ & $\mathrm{O}_{2}$ \\
\hline
\end{tabular}

Keterangan: $\mathrm{O}_{1}$ : angket awal pada kelompok eksperimen

$\mathrm{X}$ : perlakuan atau treatment pada kelompok eksperimen

$\mathrm{O}_{2}$ : angket akhir pada kelompok eksperimen).

Populasi target dalam penelitian ini adalah seluruh siswa SMPN 15 Kota Bekasi, dimaan untuk Kelas VII terdapat 9 Kelas yaitu VIIa, VIIb, VIIc, VIId, VIIe, VIIf, VIIg, VIIh, VIIi. Pengambilan sampel dengan menentukan satu kelas dari 9 kelas VII yang terdapat di SMPN 15 Kota Bekasi secara acak yaitu kelas VIIb, dimana terdapat 31 orang sebagai sampel. Variabel tindakan (X) dalam penelitian ini adalah pendekatan konstruktivisme dalam pembelajaran matematika, yaitu pendekatan yang memungkinkan siswa belajar dari mengalami, pembelajaran dikemas menjadi proses mengkonstruksi bukan menerima pengetahuan, siswa membangun sendiri pengetahuan mereka melalui keterlibatannya secara aktif dalam proses belajar mengajar. Variabel terikat (Y) adalah karakter kepercayaan diri siswa dalam pembelajaran matematika kelas VIIb SMPN 15 Kota Bekasi. Teknik analisis data dengan menggunakan uji persyaratan analisis normalitas dan menguji hipotesis. 


\section{HASIL PENELITIAN}

Data karakter kepercayaan diri siswa sebelum dan sesudah serta selisih dari 31 siswa yang diberi perlakuan dalam pembelajaran matematika dengan menggunakan pendekatan konstruktivisme dari 31 siswa serta selisih sebagai berikut:

\section{Deskripsi Data Hasil Penelitian}

Tabel 2. Statistik Deskriptif Hasil Penelitian

\begin{tabular}{cccc}
\hline Statistik & $\begin{array}{c}\text { Karakter Kepercayaan } \\
\text { Diri Awal Siswa }\end{array}$ & $\begin{array}{c}\text { Karakter Kepercayaan } \\
\text { Diri Akhir Siswa }\end{array}$ & $\begin{array}{c}\text { Selisih Karakter } \\
\text { Kepercayaan Diri Siswa }\end{array}$ \\
\hline N (jumlah siswa) & 31 & 31 & 31 \\
Nilai minimum & 3,97 & 6,66 & 2,69 \\
Nilai maksimum & 8,57 & 10 & 1,43 \\
Modus & 7,14 & 8,89 & 1,75 \\
Rata-rata & 6,67 & 8,56 & 1,89 \\
Simpangan baku & 1,28 & 0,88 & 0,40 \\
Q1 (kuartil 1) & 6,19 & 8,01 & 1,82 \\
Q2 (kuartil II/median) & 7,09 & 8,65 & 1,56 \\
Q3 (Kuartil III) & 7,71 & 9,29 & 1,58 \\
\hline
\end{tabular}

Tabel distribusi frekuensi dari selisih karakter kepercayaan diri akhir siswa dengan karakter kepercayaan diri awal siswa pada kelas eksperimen dapat dilihat pada tabel histogram sebagai berikut:

Tabel 2. Distribusi Frekuensi Selisih Karakter Kepercayaan Diri Akhir Siswa dengan Karakter Kepercayaan Diri Awal Siswa Kelas Eksperimen

\begin{tabular}{cccccccc}
\hline No & Interval Kelas & $\mathrm{x}_{\mathrm{i}}$ & Batas Nyata & $\mathrm{F}_{\text {abs }}$ & $\mathrm{F}_{\mathrm{i}} \mathrm{X}_{\mathrm{i}}$ & $\mathrm{F}_{\text {kum }}$ & $\mathrm{F}_{\text {rel }}$ \\
\hline 1. & $0,5-1,1$ & 0,8 & $0,45-1,15$ & 9 & 7,2 & 9 & $29 \%$ \\
2. & $1,2-1,8$ & 1,5 & $1,15-1,85$ & 8 & 12 & 17 & $26 \%$ \\
3. & $1,9-2,5$ & 2,2 & $1,85-2,55$ & 7 & 15,4 & 24 & $22 \%$ \\
4. & $2,6-3,2$ & 2,9 & $2,55-3,25$ & 3 & 8,7 & 27 & $10 \%$ \\
5. & $3,3-3,9$ & 3,6 & $3,25-3,95$ & 1 & 3,6 & 28 & $3 \%$ \\
6. & $4,0-4,6$ & 4,3 & $3,95-4,65$ & 3 & 12,9 & 31 & $10 \%$ \\
\hline \multicolumn{7}{c}{ Jumlah } & 31 \\
\hline
\end{tabular}

Berdasarkan tabel dan histogram di atas, terlihat bahwa jumlah siswa yang berada diatas selisih rata-rata karakter kepercayaan diri siswa ada 7 orang $(23 \%)$, sedangkan siswa yang berada dibawah selisih rata-rata kepercayaan diri siswa ada 17 orang (55\%) dan yang ada di kelas selisih rata-rata karakter kepercayaan diri siswa sebanyak 7 orang (22\%).

\section{Uji Normalitas Sebelum Perlakuan}

Hasil pengujian untuk karakter kepercayaan diri awal siswa diperoleh nilai LO = 0,0932 dan Ltabel $=0,1591$ pada taraf signifikan $\alpha=0,05$ untuk $n=31$ (Perhitungan selengkapnya terdapat pada lampiran 7 halaman 93). Berdasarkan hasil tersebut, maka nilai LO kelas eksperimen kurang dari Ltabel, maka dapat disimpulkan karakter kapercayaan diri awal siswa kelas eksperimen relatif berdistribusi normal.

\section{Uji Normalitas Sesudah Perlakuan}

Hasil pengujian untuk karakter kepercayaan diri akhir siswa diperoleh nilai LO = 0,1241 dan Ltabel $=0,1591$ pada taraf signifikan $\alpha=0,05$ untuk $n=31$ (Perhitungan selengkapnya terdapat pada lampiran 8 halaman 95). Berdasarkan hasil tersebut, maka nilai LO kelas eksperimen kurang dari Ltabel, maka dapat disimpulkan karakter kapercayaan diri awal siswa kelas eksperimen relatif berdistribusi normal. 


\section{Pengujian Hipotesis}

Hasil perhitungan diperoleh nilai thitung $=17,782$ dan $t_{\text {tabel }}=1,645$ dengan $\mathrm{dk}=31$ pada taraf signifikasi $\alpha=0,05$. Jadi, thitung $>t_{\text {tabel }}(17,782>1,645)$ ini menunjukkan bahwa hipotesis nol $\left(\mathrm{H}_{0}\right)$ ditolak dan hipotesis kerja $\left(\mathrm{H}_{1}\right)$ diterima.

\section{PEMBAHASAN}

Karakter Kepercayaan diri siswa ditentukan oleh bagaimana guru di sekolah mampu menggunakan pendekatan yang menstimulasi siswa untuk berpartisipasi secara aktif. Pendekatan yang sesuai untuk menumbuhkan partisipasi aktif siswa dalam pembelajaran adalah pendekatan konstruktivisme. Pendekatan konstruktivisme merupakan pendekatan dalam pembelajaran yang berfokus pada siswa, dimana peran guru sebagai fasilitator, motivator, pengarah dalam membantu siswa untuk membangun pengetahuannya, serta siswa belajar aktif untuk menemukan sesuatu.

Berdasarkan hasil penelitian dan perhitungan secara statistik dengan menggunakan uji-t pada $\alpha$ $=0,05$ diperoleh harga $t_{\text {hitung }}=17,782$ lebih besar dari $t_{\text {tabel }}=1,645$. Hal ini menunjukkan bahwa hipotesis nol $\left(\mathrm{H}_{0}\right)$ ditolak dan hipotesis kerja $\left(\mathrm{H}_{1}\right)$ diterima. Dengan ditolaknya $\mathrm{H}_{0}$ dari hasil pengujian hipotesis, maka dapat disimpulkan bahwa terdapat pengaruh signifikan pendekatan konstruktivisme terhadap karakter kepercayaan diri siswa dalam pembelajaran matematika kelas VIIb SMPN 15 Kota Bekasi.

Perbedaan karakter kepercayaan diri siswa tersebut dapat terlihat dari rata-rata karakter kepercayaan diri siswa sebelum dan sesudah diberi perlakuan dengan pendekatan konstruktivisme yaitu 6,67 dan 8,56 dengan selisih 1,89. Hal ini disebabkan karena dengan pendekatan konstruktivisme siswa dapat membangun pengetahuannya berdasarkan pengetahuan dan pengalaman yang telah dimilikinya, siswa juga didorong untuk menemukan cara menyelesaikan masalah dan mempresentasikan masalah tersebut sesuai pengetahuan yang dimilikinya.

Pembelajaran matematika dengan menggunakan pendekatan konstruktivisme, dimana guru mengaktifkan pengetahuan yang sudah dimiliki siswa melalui sebuah penyelidikan atau sharing kepada sesama siswa, kemudian guru memberi kesempatan kepada siswa untuk mengemukakan pendapatnya dan disimpulkan bersama-sama oleh siswa dan guru, sehingga tercipta lingkungan belajar yang aktif dan kondusif, serta evaluasi terjadi selama proses pembelajaran berlangsung. Dengan demikian karakter kepercayaan diri yang dimiliki siswa dapat meningkat.

\section{KESIMPULAN}

Berdasarkan hasil penelitian data yang diperoleh menggunakan uji-t diketahui bahwa $t_{\text {hitung }}=$ 17,782 dan $t_{\text {tabel }}=1,645$ dengan $d k=31$ pada taraf signifikasi $\alpha=0,05$. Jadi, $t_{\text {hitung }}>t_{\text {tabel }}(17,782>1,645)$ ini menunjukkan bahwa hipotesis nol $\left(\mathrm{H}_{0}\right)$ ditolak dan hipotesis kerja $\left(\mathrm{H}_{1}\right)$ diterima. Berdasarkan analisis hasil penelitian di atas maka dapat disimpulkan bahwa terdapat pengaruh signifikan pendekatan konstruktivisme terhadap karakter kepercayaan diri siswa dalam pembelajaran matematika kelas VIIb SMPN 15 Kota Bekasi

\section{Daftar Pustaka}

Abidin, M. Z., Solihatin, E., Sumantri, M. S., \& Adiansha, A. A. (2018). Effect of Problem-Based Learning ( PBL) and Learning Learning to Learning Result (Experimental Study on Grade V Students at SD Negeri Mekarsari ). 6(7), 1046-1050. https://doi.org/10.12691/education-6-7-24

Adiansha, A. A., \& Sumantri, M. S. (2017). The Effect of Brain Based Learning Model and Creative Thinking on the Ability of Mathematics Concept of Elementary Students. 5(12), 1195-1199. https://doi.org/10.12691/education-5-12-4 
Adiansha, A. A., Sumantri, M. S., \& Makmuri, M. (2018). Pengaruh model brain based learning terhadap kemampuan komunikasi matematis siswa ditinjau dari kreativitas. Premiere Educandum : Jurnal Pendidikan Dasar Dan Pembelajaran, 8(2), 127. https://doi.org/10.25273/pe.v8i2.2905

Afriani, D. A. (2019). Pelaksanaan Pendidikan Agama Islam Di Lingkungan Keluarga, Sekolah Dan Masyarakat. Jurnal ZIRAH, 1(1).

Alsulami, S. (2016). Toward a Constructivist Approach in Saudi Education. English Language Teaching, 9(12), 104. https://doi.org/10.5539/elt.v9n12p104

Arumdini, S., Winoto, Y., \& Anwar, R. K. (2016). Hubungan Antara Pola Asuh Orang Tua Dengan Minat Baca Anak. Jurnal Kajian Informasi Dan Perpustakaan, 4(2), 171. https://doi.org/10.24198/jkip.v4i2.8430

Bozkurt, G. (2017). Social Constructivism: Does It Succeed in Reconciling Individual Cognition with Social Teaching and Learning Practices in Mathematics?, Journal of Education and Practice, 2017. Journal of Education and Practice, 8(3), 210-218. Retrieved from https://eric.ed.gov/?id=EJ1131532

Cheeseman, J., \& Klooger, M. (2018). Mathematics teachers: Dealing with difference. Australian Primary Mathematics Classroom, 23(3), 27-30.

Deni, A. U., \& Ifdil. (2013). Kepercayaan Diri Ditinjau dari Pola Asuh Orang Tua pada Siswa Kelas VII (Studi Kasus). Indonesian Journal of Guidance and Counseling, 2(4), 9-16.

Ergen, G. (2019). Value Literacy - A New Model for Education of Character and Values. In Educational Policy Analysis and Strategic Research (Vol. 14). https://doi.org/10.29329/epasr.2019.201.3

Fatahi, S. (2019). An experimental study on an adaptive e-learning environment based on learner's personality and emotion. Education and Information Technologies, 24(4), 2225-2241. https://doi.org/10.1007/s10639-019-09868-5

Hariawan, R., Ulfatin, N., Huda A. Y., M., \& Arifin, I. (2019). Contributions Management of Parenting and Education Program to Strengthen the Service Three Early Childhood Education Center. International Education Studies, 12(2), 100. https://doi.org/10.5539/ies.v12n2p100

Kosnik, C., Menna, L., Dharamshi, P., \& Beck, C. (2018). Constructivism as a framework for literacy teacher education courses: the cases of six literacy teacher educators. European Journal of Teacher Education, 41(1), 105-119. https://doi.org/10.1080/02619768.2017.1372742

Lowery-Moore, H., Latimer, R., \& Villate, V. (2016). The Essence of Teacher Leadership: A Phenomenological Inquiry of Professional Growth. International Journal of Teacher Leadership, 7(1), $1-16$.

Misykah, Z., \& Adiansha, A. A. (2018). Effective teaching for increase higher-order thinking skills (hots) in education of elementary school. International Conference on Mathematics and Science Education of Universitas Pendidikan Indonesi, 3(1), 658-664.

ÖNDER, M. (2018). Contribution of Plays and Toys to Children's Value Education. Asian Journal of Education and Training, 4(3), 146-149. https://doi.org/10.20448/journal.522.2018.42.146.149

Parida, I., Winarsih, M., Maksum, A., \& Adiansha, A. A. (2018). Improving the Ability of Mathematic Communication through the Realistic Mathematic Education Approach ( RME ) at the Student Class Iv New SDN Karang 04 Cikarang Utara-Bekasi. 6(8), 1063-1071. https://doi.org/10.12691/education-6-8-1

Rahayu, W., Danugiri, H. D., Sopiany, H. N., \& Masalah, A. L. B. (2018). Miskonsepsi Matematis 
Siswa. Prosiding Seminar Nasional Matematika Dan Pendidikan Matematika (Sesiomadika) 2018, (April 2017), 274-278.

Sokip, Akhyak, Soim, Tanzeh, A., \& Kojin. (2019). Character building in islamic society: A case study of muslim families in tulungagung, East Java, Indonesia. Journal of Social Studies Education Research, 10(2), 224-242.

Soruç, A., \& Griffiths, C. (2017). English as a medium of instruction: students' strategies. ELT Journal, 72(1), 38-48. https://doi.org/10.1093/elt/ccx017

Subianto, J. (2013). Peran Keluarga, Sekolah, Dan Masyarakat Dalam Pembentukan Karakter Berkualitas. Edukasia: Jurnal Penelitian Pendidikan Islam, 8(2), 331-354. https://doi.org/10.21043/edukasia.v8i2.757

Suparlan, S. (2019). Teori Konstruktivisme dalam Pembelajaran. Islamika, 1(2), 79-88. https://doi.org/10.36088/islamika.v1i2.208

Syam, A. \& A. (2017). Pengaruh Kepercayaan Diri ( Self Confidence ) Berbasis Kaderisasi Imm Terhadap Prestasi Belajar Mahasiswa ( Studi Kasus Di Program Studi Pendidikan Biologi Fakultas Keguruan Dan Ilmu Pendidikan Universitas Muhammadiyah Parepare ). Jurnal Biotek, 5, 87-102. Retrieved from http://journal.uinalauddin.ac.id/index.php/biotek/article/viewFile/3448/3243

Tan, C. (2017). Constructivism and pedagogical reform in China: issues and challenges. Globalisation, Societies and Education, 15(2), 238-247. https://doi.org/10.1080/14767724.2015.1105737

Watson, J., \& Beswick, K. (n.d.). Proceedings of the 30th annual conference of the Mathematics Education Research Group of Australasia Edited by.

Zubaidah, S. (2019). Pendidikan Karakter Terintegrasi Keterampilan Abad Ke-21. Jurnal Penelitian Dan Pengkajian Ilmu Pendidikan: E-Saintika, 3(2), 1-24. https://doi.org/https://doi.org/10.36312/esaintika.v3i2.125 